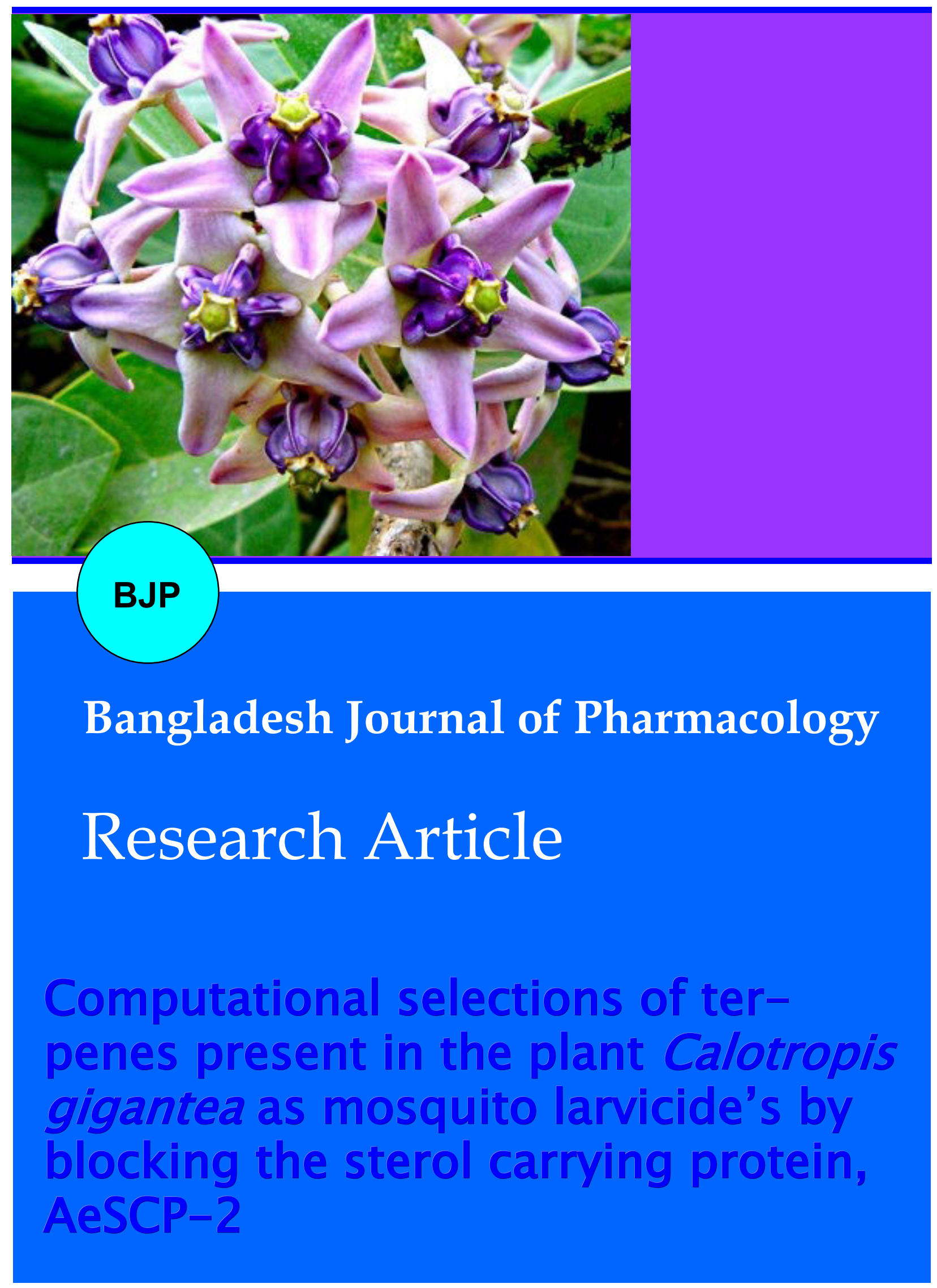


Abstracted/indexed in Academic Search Complete, Asia Journals Online, Bangladesh Journals Online, Biological Abstracts, BIOSIS Previews, CAB Abstracts, Current Abstracts, Directory of Open Access Journals, EMBASE/Excerpta Medica, Google Scholar, HINARI (WHO), International Pharmaceutical Abstracts, Open J-gate, Science Citation Index Expanded, SCOPUS and Social Sciences Citation Index;

ISSN: $1991-0088$

\title{
Computational selections of terpenes present in the plant Calotropis gigantea as mosquito larvicide's by blocking the sterol carrying protein, AeSCP-2
}

\author{
P. Suresh Kumar'1, A. Chezhian'1, P. Senthil Raja² and J. Sathiyapriya ${ }^{3}$ \\ ${ }^{1}$ Faculty of Marine Sciences, CAS in Marine Biology, Annamalai University, Parangipettai 608 502, India; \\ ${ }^{2}$ Department of Zoology, Annamalai University, Chidambaram 608 001, India; ${ }^{3}$ Department of Biochemistry, \\ Annamalai University, Chidambaram 608 001, India.
}

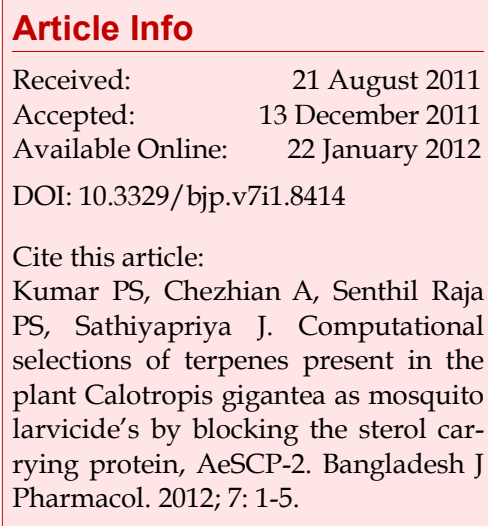

\begin{abstract}
The present study reports the phytochemical properties of Calotropis gigantea (Asclepiadaceae) commonly known as milk weed. In addition, in silico docking analysis was also carried out to assess the mosquito larvicidal potential of three terpene compounds isolated from C. gigantea. Considerable amount of primary metabolites, essential macro and micro nutrients were documented in the plant. The GC-MS analysis of the chloroform extract revealed the presence of eight terpenes in the plant. From the docking studies it is evident that $a$-amyrin has a great potential against AeSCP-2. The phytochemical screening and docking results gives strong baseline information for the posterity.
\end{abstract}

\section{Introduction}

Calotropis gigantea (Asclepiadaceae), known as milk weed, is a common wasteland weed, drought resistant, salt tolerant, grows wild up throughout India (Sastry and Kavathekar, 1990). It is one of the peculiar plants not consumed by grazing animals (Sharma, 1934).

The identified phytochemicals in this plant are usharin, gigantin, $a$ and $\beta$-calotropeol, $\beta$-amyrin, fatty acids, hydrocarbons, a mixture of tetracyclic triterpene compounds, sterols, and giganteol (Murti and Seshadri, 1943, 1945a,b). Cardenolide, calotropin (Kupchan et al., 1964), a-amyrin, $\beta$-amyrin, taraxasterol, $\beta$-sitosterol, $a$ amyrin methylbutazone, $\beta$-amyrin methylbutazone, $a$ amyrin acetate, $\beta$-amyrin acetate, taraxasteryl acetate, lupeol acetate $\mathrm{B}$, gigantursenyl acetate $\mathrm{A}$, gigantursenyl acetate B (Sen et al., 1992; Habib et al., 2007), flavonol glycoside, akundarol, uscharidin, calotropin, frugoside, calotroposides $A$ to $G$ were isolated. Thus, the plant has immense potential to cure various diseases and disorders (CSIR, 1992; Duke, 1992; Chitme et al., 2004; Tenpe et al., 2007). The present study reports in silico docking analysis carried out to assess the mosquito larvicidal potential of four terpene compounds isolated from C. gigantea.

\section{Materials and Methods \\ Plant material collection and processing}

The aerial parts of the plant parts were collected from Tiruchirappalli, Tamil Nadu, India, on September 2008. The collected plant materials were then brought in to the laboratory and washed thoroughly with the distilled water to remove the dirt and other contaminations. Then the washed plant materials were dried carefully under shade, at room temperature so as to retain their fresh green colour, and also to prevent decomposition 
of the active compounds. The dried leaves were powdered using a stone grinder. The powdered materials were stored in airtight, dark, glass container to prevent photochemical reactions.

\section{Phytochemical analysis}

The drugs were used to determine the organic carbon (Walkley and Black, 1934); carbohydrate (Hedge and Hofreiter, 1962); protein (Lowry et al., 1951); lipid (Folch et al., 1957); ash content (Renaud et al., 1994); total nitrogen (Balasubramanian and Sadasivam, 1987); phosphorous, potassium (Jackson, 1973); calcium, magnesium, zinc, copper, iron, manganese, boron, molybdenum, chromium, nickel, cadmium, lead, cobalt, mercury, arsenic, cyanide, Selenium and silver (Baker and Suhr, 1982; Allen, 1989).

\section{Elemental analysis}

Two grams of dried sample was digested in a mixture of nitric acid, sulfuric acid and perchloric acid in the ratio 11:6:3, for 24 hours to remove the organic matters. The digested sample was made up to $100 \mathrm{~mL}$ and used for the assay of the trace elements through atomic absorption spectrophotometer (AAS- Varion 200AA) using suitable hollow-cathode lamps. Appropriate working standard was prepared for each element. All elements were determined through this procedure. A blank reading was also obtained.

\section{Extraction and GC-MS analysis of terpenes}

The crude drug was subjected to extraction with analytical grade solvent of chloroform for GC-MS analysis. 25 $\mathrm{g}$ of the crude drug was taken in a round bottom flask and $50 \mathrm{~mL}$ of analytical grade chloroform was added and refluxed for 8 hours. After completion of the 8 hours, the round bottom flask was cooled and the extract was filtered through the Buchner funnel. The extract was evaporated to dryness under nitrogen atmosphere using turbo evaporator. The residue obtained was dissolved in $2 \mathrm{~mL}$ chloroform and transferred into the GC vial and injected into the GCMS port. GC-MS analysis was performed on an Agilent gas chromatograph model $6890 \mathrm{~N}$ coupled to an Agilent $5973 \mathrm{~N}$ mass selective detector. Analytes were separated on an HP-5MS capillary column $(30 \mathrm{~m} \times 0.25 \mathrm{~mm} \times$ $1.0 \mu \mathrm{L})$ by applying the following temperature program: $40^{\circ} \mathrm{C}$ for $5 \mathrm{~min}, 40-70^{\circ} \mathrm{C}$ at $2^{\circ} \mathrm{C} / \mathrm{min}, 70^{\circ} \mathrm{C}$ for $2 \mathrm{~min}, 70-120^{\circ} \mathrm{C}$ at $3^{\circ} \mathrm{C} / \mathrm{min}, 120-150^{\circ} \mathrm{C}$ at $5^{\circ} \mathrm{C} / \mathrm{min}, 150$ $-220^{\circ} \mathrm{C}$ at $10^{\circ} \mathrm{C} / \mathrm{min}$ and then $220^{\circ} \mathrm{C}$ for $2 \mathrm{~min}$. Transfer line temperature was $280^{\circ} \mathrm{C}$. Mass detector conditions were: Electronic impact (EI) mode at $70 \mathrm{eV}$; source temperature: $230^{\circ} \mathrm{C}$; scanning rate 2.88 scan S-1; mass scanning range: $\mathrm{m} / \mathrm{z} 29-540$. Carrier gas was helium at $1.0 \mathrm{~mL} / \mathrm{min}$. The tentative identification of volatile components was achieved by comparing the mass spectra with the data system library (NIST) and other published spectra (Mass Spectrometry Data Centre.,
1974), supported by retention index data, which were compared with available literature retention indices. All compounds were quantified as 3-octanol equivalents.

\section{Docking studies}

The present biocomputational investigation was carried out to identify the candidate therapeutic terpene compounds having potential for inhibiting the growth of mosquito larvae. The 3-D crystal structure of the protein AeSCP-2 was retrieved from the protein data bank (PDB). AeSCP-2 protein is a low molecular weight with high levels of expression in the midgut of the larvae and high binding affinity to cholesterol in the Aedes aegypti mosquito species (Kitamura et al., 1996). Structural and active site enumeration were done by using pymol molecular visualization software and CASTP (Computed Atlas of Surface Topography of Proteins). Four phytochemicals namely a-amyrin, oleanolic acid, 5-norbornene-2-carboxylic acid and pyrethrin were screened against the protein AeSCP-2. The details of these phytochemical were obtained from pubchem database and there chemical structures were generated from SMILES notation (Simplified Molecular Input Line Entry Specification) by using the Chemsketch Software (www.acdlabs.com). The molecular docking analysis was performed using Argus Lab 4.0 which is widely distributed public domain molecular docking software.

\section{Results and Discussion}

Leaf sample of C. gigantea was analyzed for the composition of ash materials and the organic carbon, primary metabolites, essential macro nutrient, essential micro nutrient and trace elements. The plant contains $1.69 \%$ of ash and $27.5 \%$ of organic carbon (Table I). The primary metabolites, carbohydrate, protein and lipids were $0.97,0.55$ and $0.29 \%$ respectively. The essential macronutrients such as nitrogen $(2.16 \%)$, phosphorous $(0.42 \%)$, potassium $(2.97 \%)$, calcium $(4.59 \%)$, magnesium $(3.16 \%)$, and sulfur $(0.48 \%)$ were found in considerable level. The essential micro nutrients were also found in considerable level. Among micronutrients the amount of iron (156.3 ppm) was the highest and molybdenum (0.1 ppm) was the lowest. The heavy metals except arsenic and cyanide, all other heavy metals were found to be present in considerable level in this plant. Lead was the most dominating heavy metal $(0.16 \mathrm{mg} / \mathrm{L})$, whereas nickel $(0.02 \mathrm{mg} / \mathrm{L})$ was the least. Compared to previous studies our results are also in considerable level. Similar study on C. procera showed varied concentrations of phytochemicals (Altaf, 1997) and similar variations were also found in our study. These differences could be due to ecological, time of collection, collection sites or may be because of increasing pollution or environmental factors. Previous 


\section{Table I}

\section{Phytochemicals present in the Calotropis gigantea}

\begin{tabular}{|lccccc|}
\hline Parameter & Quantity $\%$ & Parameter & Quantity & Parameter & Quantity \\
\hline Ash & 1.7 & Magnesium & $3.2 \%$ & Nickel & $0.02 \mathrm{ppm}$ \\
Organic carbon & 27.5 & Sulfur & $0.5 \%$ & Cadmium & $0.04 \mathrm{ppm}$ \\
Carbohydrate & 1.0 & Zinc & $3.2 \mathrm{ppm}$ & Lead & $0.16 \mathrm{ppm}$ \\
Proteins & 0.6 & Copper & $1.0 \mathrm{ppm}$ & Cobalt & $0.05 \mathrm{ppm}$ \\
Lipids & 0.3 & Iron & $156.3 \mathrm{ppm}$ & Mercury & $0.001 \mathrm{ppm}$ \\
Nitrogen & 2.2 & Manganese & $22.6 \mathrm{ppm}$ & Arsenic & $\mathrm{bdl}$ \\
Phosphorous & 0.4 & Boron & $0.1 \mathrm{ppm}$ & Cyanide & $\mathrm{bdl}$ \\
Potassium & 3.0 & Molybdenum & $0.1 \mathrm{ppm}$ & Selenium & $0.59 \mathrm{ppm}$ \\
Calcium & 4.6 & Chromium & $0.002 \mathrm{ppm}$ & Silver & $0.02 \mathrm{ppm}$ \\
\hline
\end{tabular}

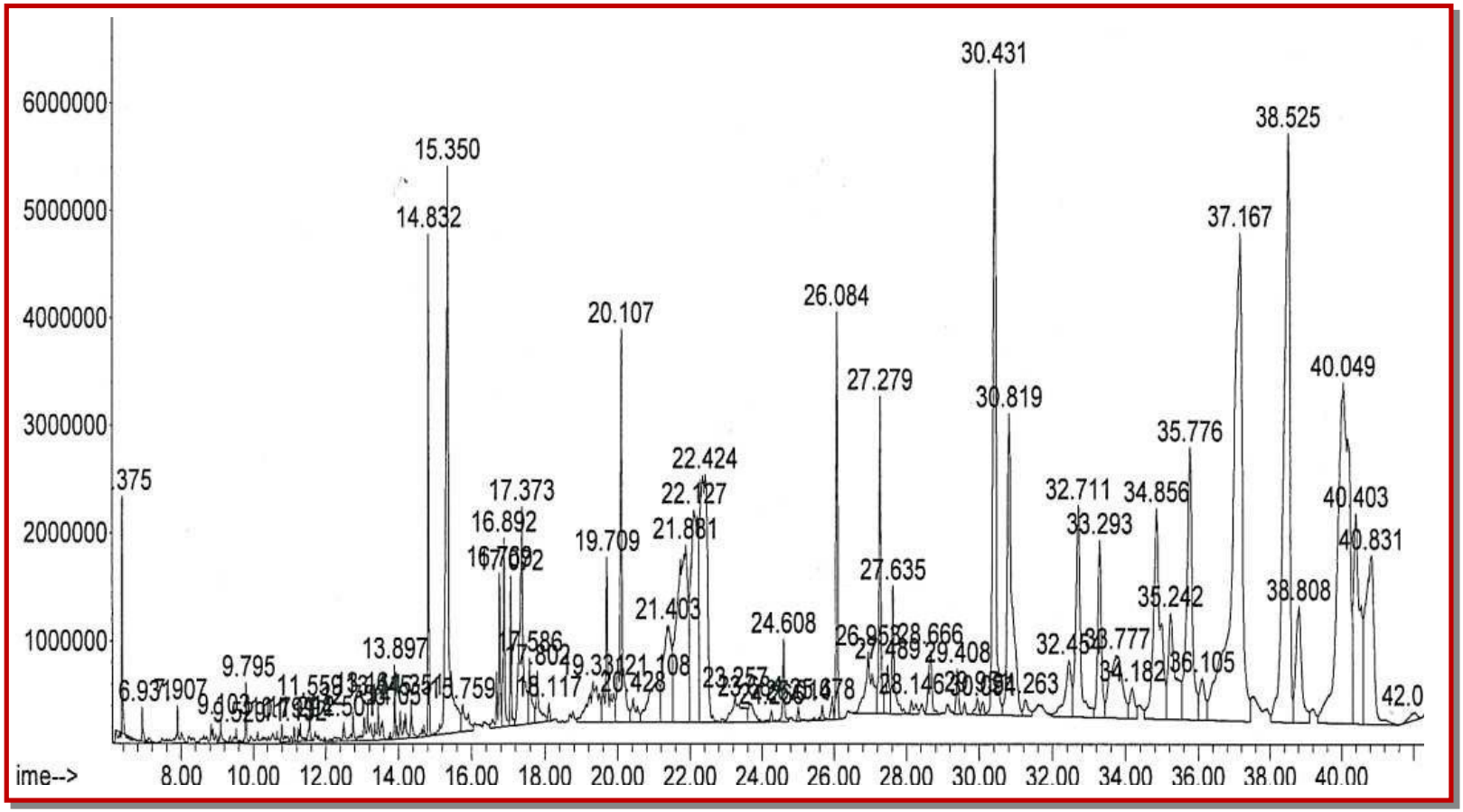

Figure 1: GC mass spectra of Calotropis gigantea

studies have also report the presence of phytochemicals like terpenes, cardenolides, flavonoids, pregnanes, nonprotein amino acid and cardiac glycoside as major constituents in Calotropis $s p$. and presence of these phytochemicals sturdily acknowledge the medicinal property of this plant (Wang et al., 2008; Ali and Gupta, 1999).

The GC mass spectra (Figure 1) showed the presence of eight terpenes in the plant namely bicyclo (3.1.1) heptane,2,6,6-trimethyl-,(1alpha, 2alpha, 5alpha); phytol; Urs-12-en-24-oic acid, 3-oxo-,methyl ester,(+)-; squalene; taraxasterol; a-amyrin; beta-amyrin and 12oleanen-3-yl acetate, (3alpha) (Table II). The 12-oleanen$3-y l$ acetate, (3alpha) was the major portion of the terpenes which showed the peak area percentage of 16.9.

Approximately 3 billion people, one half of the world's population, live in at risk regions for malaria infection. This leads to about 250 million malaria cases every year and nearly one million deaths. One of the most crucial obstacles for eradicating malaria is a widespread resistance of malarial parasite to almost all chemotherapeutic agents (Snow et al., 2005).

Considering the dreadful global issue of the health, in silico docking analysis was carried out. Four phytochemicals namely a-amyrin, oleanolic acid, 5-norbornene-2-carboxylic acid and pyrethrin were selected for screening against the protein AeSCP-2. The compounds 


\begin{tabular}{|c|c|c|c|c|c|c|}
\hline \multicolumn{7}{|c|}{ Table II } \\
\hline \multicolumn{7}{|c|}{ Terpenes screened from Calotropis gigantea } \\
\hline Sl. No. & Retention time & Peak area \% & Compound name & CID No. & Molecular formula & M. Wt $[\mathrm{g} / \mathrm{mol}]$ \\
\hline 1 & 13.8 & 0.5 & $\begin{array}{l}\text { 5-Norbornene-2- } \\
\text { carboxylic acid }\end{array}$ & 78949 & $\mathrm{C} 8 \mathrm{H} 10 \mathrm{O} 2$ & 138.2 \\
\hline 2 & 16.8 & 1.1 & Phytol & 5280435 & $\mathrm{C} 20 \mathrm{H} 40 \mathrm{O}$ & 296.5 \\
\hline 3 & 26.0 & 1.8 & Squalene & 1105 & $\mathrm{C} 30 \mathrm{H} 50$ & 410.7 \\
\hline 4 & 35.7 & 5.8 & alpha-Amyrin & 225688 & $\mathrm{C} 30 \mathrm{H} 50 \mathrm{O}$ & 426.7 \\
\hline 5 & 37.0 & 8.4 & beta-Amyrin & 73145 & $\mathrm{C} 30 \mathrm{H} 50 \mathrm{O}$ & 426.7 \\
\hline 5 & 38.4 & 16.9 & Oleanolic Acid & 10494 & $\mathrm{C} 30 \mathrm{H} 48 \mathrm{O} 3$ & 456.7 \\
\hline 6 & 40.2 & 4.2 & Taraxasterol & 5270604 & $\mathrm{C} 30 \mathrm{H} 50 \mathrm{O}$ & 426.7 \\
\hline 7 & - & 47.8 & Other compounds & - & - & - \\
\hline
\end{tabular}

\begin{tabular}{|c|c|c|c|c|c|}
\hline \multicolumn{6}{|c|}{ Table III } \\
\hline \multicolumn{6}{|c|}{ Docking studies } \\
\hline Compound name & Pubchem ID & $\begin{array}{l}\text { Compound } \\
\text { structure }\end{array}$ & $\begin{array}{l}\text { Molecular weight } \\
\text { (g/mol) }\end{array}$ & $\begin{array}{l}\text { Hydrogen donor/ } \\
\text { acceptor }\end{array}$ & $\begin{array}{l}\text { Docking energy } \\
\text { level (Kcal/mol) }\end{array}$ \\
\hline $\begin{array}{l}\text { 5-Norbornene-2- } \\
\text { carboxylic acid }\end{array}$ & CID: 78949 & & 138.2 & 1,2 & -8.4 \\
\hline Alpha-amyrin & CID: 25688 & & 426.7 & 1,1 & -14.1 \\
\hline Oleanolic acid & CID: 10494 & & 456.7 & 2,3 & -13.8 \\
\hline
\end{tabular}

were docked in Argus lab 4.0. Docking energy was found to be $-14.1213 \mathrm{Kcal} / \mathrm{mol},-13.7876 \mathrm{Kcal} / \mathrm{mol}$ and $8.3558 \mathrm{Kcal} / \mathrm{mol}$ in a-amyrin, oleanolic acid and 5norbornene-2-Carboxylic acid respectively (Table III). Hence, from the docking studies it is evident that $a$ amyrin (C. gigantea derived terpene) has a great potential against AeSCP-2.

Medicinal plants are being probed as an alternate source to get therapeutic compounds based on their medicinal properties. C. gigantea is easily available in most of the agricultural and non-agricultural fields and the usage of this plant for medicinal purpose was reported by several researchers. We conclude that $C$. gigantea represents a rich source of valuable medicinal compounds and leaves of $C$. gigantea contain a-amyrin which could be a potential source for inhibiting the AeSCP-2.

\section{References}

Ali M, Gupta J. New pentacyclic triterpenic esters from the roots of Calotropis procera. Indian J Chem. 1999; 38: 877-81.

Allen SE. Chemical analysis of ecological materials. 2nd ed. Blackwell Science Publishers, Oxford, 1989.

Altaf WJ. Effect of motorway traffic emission on roadside wildplants in Saudi Arabia. Radioanalytical Nuclear Chem. 1997; 217: 91-94.

Baker DE, Suhr NH. Atomic absorption and flame emission spectrometry. In: Methods of soil analysis. USA, American Society of Agronomy, 1982, pp 13-76.

Balasubramanian T, Sadasivam S. Changes in starch, oil, protein and amino acids in developing seeds of okra (Abelmoschus esculentus L. Moench). Plant Foods Human Nutri. (Formerly Qualitas Plantarum). 1987; 37: 41-46.

Chitme HR, Chandra M, Kaushik S. Studies on anti-diarrhoeal 
activity of Calotropis gigantea R. Br. in experimental animals. J Pharm Pharmaceut Sci. 2004; 25: 70-75.

CSIR. The wealth of India: Raw materials. Vol: 3. New Delhi, Publication and Information Directorate, 1992, pp 78-84.

Duke JA. Handbook of biologically active phytochemicals and their activities. Florida, CRC Press, 1992, pp 22-25.

Folch J, Lees M, Sloane Stanley GH. A simple method for the isolation and purification of total lipids from animal tissues. J Biol Chem. 1957; 226: 497-509.

Habib MR, Nikkon F, Rahman M, Haque ME, Karim MR. Isolation of stigmasterol and $\beta$-sitosterol from methanolic extract of root bark of Calotropis gigantea (Linn). Pak J Biol Sci. 2007; 10: 4174-76.

Hedge JE, Hofreiter BT. In: Carbohydrate chemistry. Whistler RL, Be Miller JN (eds). New York, Academic Press, 1962.

Jackson ML. Soil chemical analysis. New Delhi, Prentice Hall of India, 1973, pp 10-144.

Kitamura T, Kobayashi S, Okada M. Regional ezpression of the transcript encoding sterol carrier protein $\mathrm{x}$-related thiolase and its regulation by homeotic genes in the midgut of Drosophila embryos. Dev Growth Differ. 1996; 38: 373-81.

Kupchan SM, Knox JR, Kelsey JE, Saenzrenauld JA. Calotropin, a cytotoxic principle isolated from Asclepias curassavica L. Science 1964; 146: 1685-86.

Lowry $\mathrm{OH}$, Rosebrough NJ, Farr AL, Randall RJ. Protein measurement with the Folin phenol reagent. J Biol Chem. 1951; 193: 265.

Mass spectrometry data centre eight peak index of mass spectra, (2nd ed., Vols 1 and 2). In collabration with ICI Ltd. (Organic Division), Reading, 1974.

Murti PBR, Seshadri TR. Chemical composition of Calotropis gigantean. Part 1. Wax and resin components of the latex.
Proc Indian Acad Sci. 1943; 18: 145-59.

Murti PBR, Seshadri TR. Chemical composition of Calotropis gigantean. Part II. Wax and resin components of the stem bark. Proc Indian Acad Sci. 1945a; 21: 8-18.

Murti PBR, Seshadri TR. Chemical composition of Calotropis gigantean: Part VI. Flowers: A comparison of the composition of the various parts of the plant. Proc Indian Acad Sci. 1945b; 21: 304-09.

Renaud SM, Parry DL, Luong-Van T. Microalgae for use in tropical aquaculture I: Gross chemical and fatty acid composition of twelve species of microalgae from the Northern Territory, Australia. J Appl Phycol. 1994; 6: 337-45.

Sastry CST, Kavathekar KY. In: Plants for reclamation of wasteland. New Delhi, Publication and Information Directorate, CSIR, 1990, pp 175-79.

Sen S, Sahu NP, Mahato SB. Flavonol glycosides from Calotropis gigantea. Phytochemistry 1992; 31: 2919-21.

Sharma GK. Calotropis procera and Calotropis gigantea. Indian J Veterinary Sci. 1934; 4: 63-74.

Snow RW, Guerra CA, Noor AM, Myint HY, Hay SI. The global distribution of clinical episodes of Plasmodium falciparum malaria. Nature 2005; 434: 214-17.

Tenpe CR, Upaganlawar AB, Dongre PA, Yeole PG. Screening of methanolic extract of Calotropis gigantea leaves for hepatoprotective activity. Indian Drugs. 2007; 44: 874-75.

Walkley A, Black IA. An examination of the Degtjareff method for determining organic carbon in soils: Effect of variations in digestion conditions and of inorganic soil constituents. Soil Sci. 1934; 63: 251-63.

Wang ZN, Wang MY, Mei WL, Han Z, Dai HF. A new cytotoxic pregnanone from Calotropis gigantean. Molecules. 2008; 13: 3033-39. 